\title{
Sustainable Business Model of Water Purification Equipment and Local Manufacturing Technology Transfer of High Adsorption Bone Char to Remove Fluoride from Groundwater
}

\author{
Min-Soo Maeng ${ }^{1}$, He-In Lee ${ }^{2}$, Jung-Seop Byun², Hyo-Jin Park², Gwy-Am Shin ${ }^{2, \dagger}$ \\ ${ }^{1}$ Department of Civil and Environmental Engineering, Dankook University, Yongin 31116, Republic of Korea \\ ${ }^{2}$ Department of Environmental and Safety Engineering, Suwon 16499, Republic of Korea
지하수 불소제거를 위한 고흡착 골탄의 현지 제조기술 이전과 정수장치의 지속 가능한 비즈니스 모델 개발

맹민수 ${ }^{1}$, 이혜인 ${ }^{2}$, 변정섭 ${ }^{2}$, 박효진 $^{2}$, 신귀암 ${ }^{2, \dagger}$

${ }^{1}$ 토목환경공학과, 단국대학교, 용인시 31116 , 대한민국

${ }^{2}$ 환경안전공학과, 아주대학교, 수원시 16499 , 대한민국

\begin{abstract}
탄자니아 아루샤에 위치한 Gongali model Co. Ltd는 지하수 불소제거를 위해서 현지에서 생산한 골탄을 이용하여 Nanofilter water station을 운영하고 있다. 현지에서 생산된 골탄은 탁도와 유기물 농도가 높아서 색도가 유발되는 문 제가 있다. 또한, 불소 흡착 효율이 낮아서 골탄의 짧은 교체 주기로 인해 유지관리 비용이 증가하는 비용적 어려움도 있다. 이를 보완하기 위해서 고흡착 골탄을 보급하기 위한 목적으로 현지형 가마를 국내에서 제작하여 현지에 보급하 는 사업을 추진하였다. 현지에서 고흡착 골탄을 생산함으로써 Nanofilter water station의 운영 효율이 증가하였으며 지 역 주민들에게 안정적으로 지속해서 식수를 제공할 수 있었다. 또한, Gongali model Co. Ltd에게 지속 가능한 비즈니 스 모델을 제시함으로써 고흡착 골탄의 지속성과 Nanofilter water station의 확산 계획을 제시하였다. 결과적으로 본 사 업을 통해서 지속적으로 저소득층과 소외계층에게 저렴한 식수를 공급할 수 있는 방안을 마련할 수 있었다.
\end{abstract}

Gongali model Co. Ltd located in Arusha, Tanzania is operating a Nanofilter water station using locally produced bone char to remove fluoride in groundwater. Bone char produced locally had a high turbidity and high concentration of organic matter, which cause color. In addition, since the fluorine adsorption efficiency is low, there is a problem in high maintenance cost due to a short replacement cycle of bone char. In order to overcome this challenge, our research team was that a local furnace was manufactured and applied for produce high adsorption bone char in Gongali model Co. Ltd. By producing high-adsorption bone char locally, the operating efficiency of the Nanofilter water station increased, and it was possible to stably and continuously provide drinking water to local residents. In addition, by presenting a sustainable business model to Gongali model Co Ltd, the persistence of high adsorption bone char and a plan to spread the Nanofilter water station were suggested. Therefore, it was possible to propose a plan to continuously supply low-cost drinking water to the low-income and the neglected class through this local project.

KEYWORDS: Business model, Fluoride removal, Furnace, Highly absorption bone char, Safe water

\footnotetext{
'To whom correspondence should be addressed.

E-mail: gwyam@ajou.ac.kr

Received: 15 May 2021, Revised: 25 May 2021,

Accepted: 25 May 2021
} 


\section{Introduction}

탄자니아, 에티오피아, 케냐, 모잠비크 등의 동아프리카 국가들은 Rift valley에 위치하고 있기 때문에 음용수로 이 용되고 있는 지하수에 고농도의 불소가 검출되는 문제가 발 생 되고 있다(Nair et al., 1984; Colombani et al., 2018; Malago et al., 2017). WHO의 불소 음용수 수질기준은 $1.5 \mathrm{mg} / \mathrm{L}$ 이 지만 동부아프리카 국가들의 지하수 불소 함유량이 5 15 $\mathrm{mg} / \mathrm{L}$ 로 확인되었다(Imran et al., 2013). 불소 농도가 $0.5 \mathrm{mg} /$ $\mathrm{L}$ 이하일 경우 충치 예방에 효과적이지만, $1.5 \mathrm{mg} / \mathrm{L}$ 이상의 불소가 함유되면 치아불소 침착증, 골격 불소증 등의 심각 한 질병을 일으킬 수 있다(Li et al., 2016; Kut et al., 2016; Jeremy et al. 2018; Vithanage et al., 2015). 이러한 문제를 해결하고자 현지에서는 불소 제거용 골탄(bone char)을 사 용하여 주민들에게 안전한 식수를 제공하고 있다 $(\mathrm{Hu}$ et al., 2017; Mohapatra et al., 2009; Loganathan et al., 2013). 골탄 은 소뼈를 태워 만들 수 있기 때문에 현지에서 조달할 수 있고 가격도 저렴하여 운영하기에 적합하다(Moreno-pirajan et al., 2011). 소뼈의 65 70\%는 무기물로 구성된 Hydroxyapatite $\left(\mathrm{HAP}, \mathrm{Ca}_{10}\left(\mathrm{PO}_{4}\right)_{6}(\mathrm{OH})_{2}\right)$ 의 $\mathrm{OH}^{-}$가 $\mathrm{F}^{-}$와 치환함으로써 지하수 의 불소를 제거한다(Medellin-Castillo et al., 2016; Aklil et al., 2004). 하지만 골탄의 낮은 불소흡착 효율 $(1 \mathrm{mg} / \mathrm{g})$ 로 인 해 교체 주기가 짧다는 것이 단점이다(Maeng et al., 2020). 또한, 현지에서 제작된 골탄은 저품질로 인해 식수에서 탁 도가 높고 유기물로 인한 색도가 발생하여 음용하기에 부 적합한 실정이다(Leyva-Ramos et al., 2010). 그래서 연구자 들은 골탄의 품질 향상과 흡착 효율을 기존 대비 5 10배로 높이기 위해서 다양한 연구결과를 도출하였다(Medlin-Castillo et al., 2007). 대부분 골탄의 표면개질 변화를 통해 불소흡 착 효율이 향상되었지만, 여전히 연구실에서 수행되었기 때 문에 현지에 보급되기 위한 현실적 어려움이 있다(ZunigaMuro et al., 2017; Kaseva et al., 2006). 최근 고흡착 골탄의 현지 생산이 가능한 연구가 수행되었으며 현지 골탄의 불 소흡착 효율 대비 약 3.7 배 이상의 효과를 얻을 수 있는 결 과를 도출하였다(Maeng et al., 2020). 또한, 기존골탄에서 문 제가 되었던 탁도 및 색도 문제도 해결할 수 있었다(Maeng et al., 2020). 하지만, 여전히 현지에서 고흡착 골탄생산을 가마 제작에 대한 연구가 미흡한 실정이다. 현지형 고흡착 골탄을 생산하기 위한 가마 제작 기술과 생산된 고흡착 골 탄을 현지에서 운영되고 있는 정수장치에 적용함으로써 주 민들에게 안전한 식수를 제공하고 긴 교체 주기를 통해서 식수 판매자들은 운영비 절감을 유도하여 판매 수익 증대 를 기대할 수 있는 비즈니스 모델의 방향성이 요구된다. Gongali model Co. Ltd(이하, Gongali)는 현지인이 운영하는
사회적 기업으로서 지하수 불소를 제거하기 위해 골탄을 사 용한 Nanofilter 정수장치를 개발하여 지역사회에 water kiosk 형태의 Nanofilter water station(NWS)를 제공하고 있다. 탄 자니아 아루샤 뿐만 아니라 주변 지역과 나라에 NWS 정수 기술을 제공하여 취약계층에게 사회적 서비스 혹은 일자리 창출 기회를 지역사회에 공헌함으로써 주민들의 삶의 질을 높이는 등의 사회적 역할을 담당하고 있다. 따라서 현지의 지속 가능한 사업 추진을 위해서 탄자니아 아루샤에 위치 한 Gongali와 협력하여 고흡착 골탄 생산 기술 이전을 통해 지속 가능한 정수 사업을 진행하였다. 아루샤 수돗물과 지 하수의 불소 농도가 각각 약 $3.8 \mathrm{mg} / \mathrm{L}$ 과 $5.1 \mathrm{mg} / \mathrm{L}$ 로 $\mathrm{WHO}$ 수질기준인 $1.5 \mathrm{mg} / \mathrm{L}$ 보다 높기 때문에 안전한 식수 공급 이 매우 시급한 실정이다. 사회적 기업인 Gongali는 탄자니 아 정부에서 제공한 현지 골탄을 이용하여 하루 $300 \mathrm{~L}$ 의 식 수를 공급할 수 있는 90개의 NWS를 아루샤 지역에 설치하 여 임대 사업 진행하고 있다. Gongali는 NWS를 통해서 현 지인 인력 고용 창출 및 안전한 식수 제공을 위한 사업 비 전으로 저렴한 식수를 주민들에게 제공하는 사업을 추진 중 에 있지만, 식수 판매원들은 기존 골탄을 통한 식수 수질 문 제와 잦은 골탄 교체로 인한 어려움을 호소하고 있다. NWS 의 운영비 중 골탄 교체 비용이 전체 $33 \%$ 를 차지하고 있기 때문에 골탄을 교체해주는 현지 사업자에게는 큰 부담이다. 주민 중 생계에 여유가 있는 시민들은 시중에 안전한 물병 을 구매하고 있지만, 많은 지역 주민들은 안전한 식수공급 처가 NWS가 유일한 방법이다. 본 사업에 제공하는 고흡착 골탄을 적용하여 NWS의 지속 가능한 비즈니스 사업을 추 진과 함께 아루샤 지역의 주민들에게 안전한 식수 공급을 위한 방안이 요구된다.

본 연구에서는 고흡착 골탄생산을 위한 현지형 가마 제 작 설계 및 매뉴얼 구축을 위해 국내에서 고흡착 골탄의 대 량생산용 가마를 제작/운영함으로써 최적 설계 및 운전조건 을 도출하였다. 그리고 현지에서 고흡착 생산을 위한 가마 를 구축하고 제작 기술을 이전하였다. 더욱이 가마를 통해 서 대량 생산할 수 있는 기술을 개발하여 이전하였다. 마지 막으로 현지에서 생산한 고흡착 골탄을 NWS에 적용하여 불소제거 처리효율을 평가하고 지속 가능한 NWS 비즈니스 운영 모델 방안을 제시하고자 한다.

\section{불소 제거를 위한 현지형 고흡착 골탄 생산 가마 제작}

\section{1. 고흡착 골탄 생산용 현지형 가마 제작 및 운영}

국내에서는 고온 전기로(LOMF-702, SCI FINETECH, $\mathrm{KOREA}$ )를 사용하여 고흡착 골탄을 만들었지만, 현지에서 
는 고온 전기로가 아닌 숫을 사용하여 가마를 운영하고 있 기 때문에 고흡착 골탄생산을 위해서는 현지형 가마 제작 이 시급한 실정이었다. 따라서 연구진들은 Figure 1과 같이 국내에서 고흡착 골탄 생산을 위해 현지형 가마의 설계디 자인과 보완점을 찾기 위해서 직접 제작하여 운영해 보았다. 또한, 가마 운영을 통해서 생산한 고흡착 골탄의 불소제거 효율 실험도 현지 골탄과 비교하여 분석하였다. 가마 운영 에 있어서 현지에서 모든 재료가 조달 될 수 있는 조건으 로 국내에서 제작하여 운영하였다.

고흡착 골탄 생산을 위한 가마운영 조건은 다음과 같다. 캠
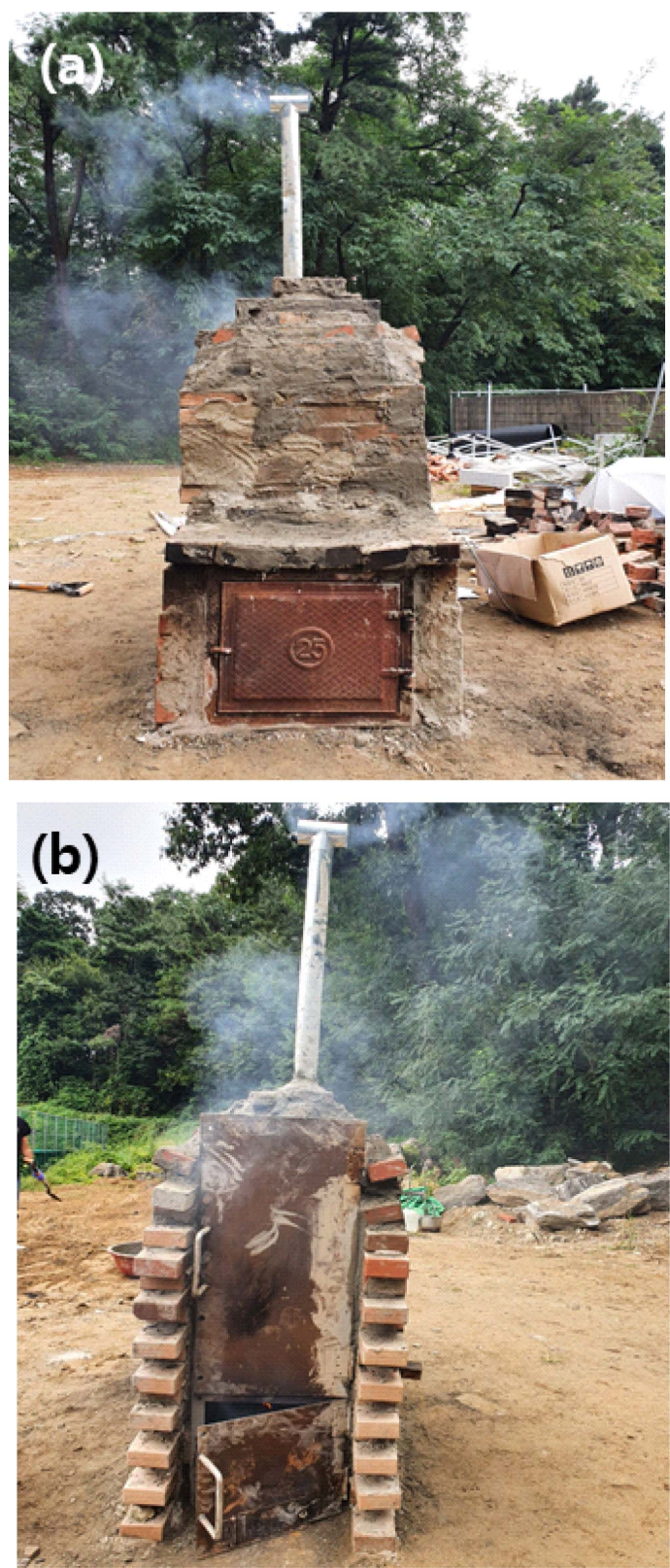

Figure 1. 가마 전면 사진(a) 가마 후면 사진(b)
핑용 그릴을 이용해서 뼈를 5단 선반에 넣고 가마 하단에 숯과 나무를 넣어 불을 피워 가마 내부 온도가 $450 \pm 50^{\circ} \mathrm{C}$ 에 온도에서 3시간 동안 태운 후 뼈를 꺼내 파쇄 후 체거름하 여 골탄으로 제작하였다. 가마 내부 온도 조절은 가마 측면 에 공기 주입구 3 개를 만들어 화력 지원시 온도가 급격히 올라갈 때 공기 주입구를 조절하는 방법으로 운영하였다. 제 작된 가마의 외부 규격은 가로·세로·높이가 각각 $50 \mathrm{~cm}, 80$ $\mathrm{cm}, 160 \mathrm{~cm}$ 이며 가마 전면부에는 화력을 지원하기 위해서 여닫이 주물문을 장착하였다. 사용된 주요 화력은 숯과 나
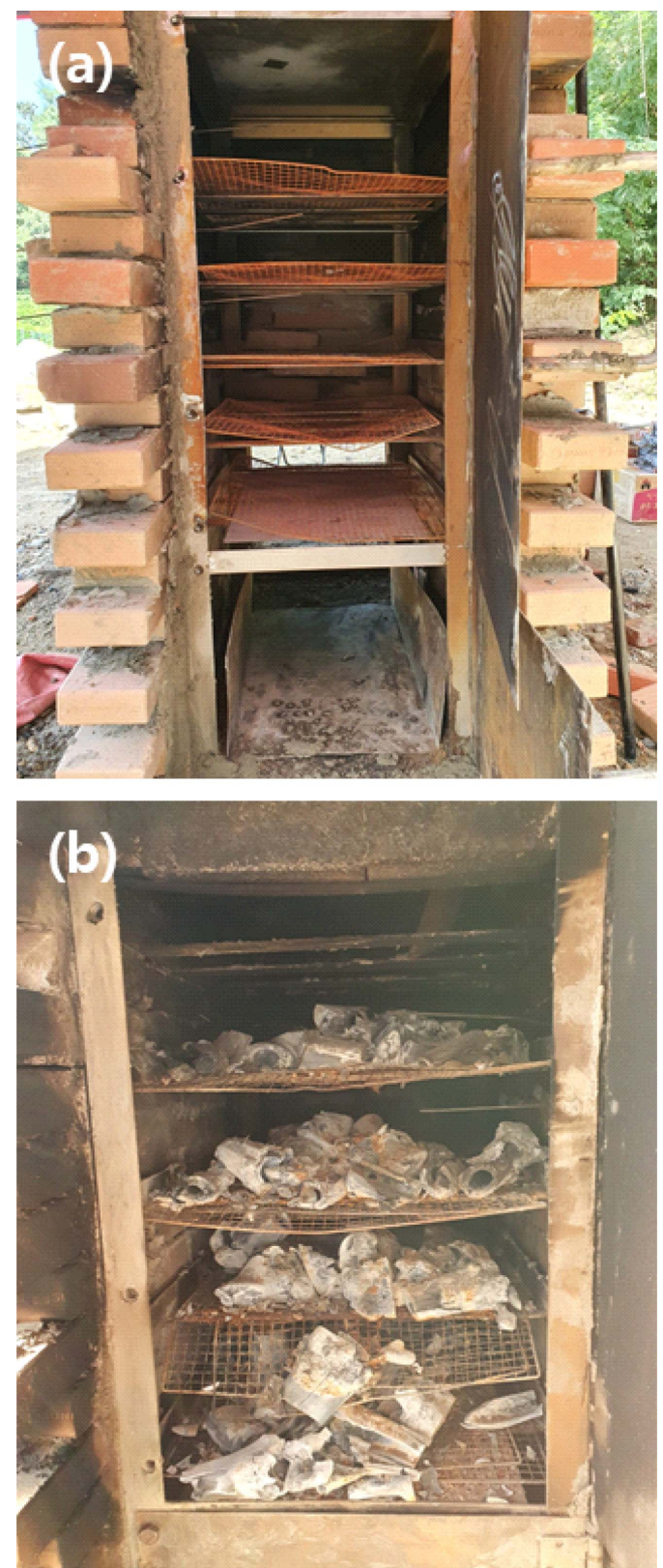

Figure 2. 가마 내부 케이지 운영 전 모습(a), 가마 운영 후 태워 진 뼈의 모습(b) 
무를 이용하였다. 가마 후면부에는 화력 조절을 위해서 가 로·세로 각각 $30 \mathrm{~cm}$ 의 유지관리 철문을 장착하였다. 가마 내 부는 Figure 2와 같이 가로·세로·높이인 $30 \mathrm{~cm}, 70 \mathrm{~cm}, 130$ $\mathrm{cm}$ 의 크기의 케이지를 만들고 하단 $30 \mathrm{~cm}$ 높이 에서부터 15 $\mathrm{cm}$ 간격으로 총 5 단으로 구성된 선반을 만들어 많은 양의 뼈를 넣을 수 있도록 제작하였다. 실험에 사용된 소뼈는 시 중에서 쉽게 구매 가능한 사골을 사용하였으며 뼈는 캠핑 용 그릴을 이용하여 가마 내부의 각 선반으로 운반하였다. 가마 상부에는 하부에서 올라오는 열을 순환시켜주기 위해 서 완만한 곡선 구조로 천장을 제작하였고 연통을 $\mathrm{T}$ 자로 만 들어 연기가 잘 배출될 수 있는 구조로 제작되었다. 뼈를 태 우는 시간은 총 3 시간이었으며 가마 내부 온도는 $450 \pm 50^{\circ} \mathrm{C}$ 로 맞추어 운영하였다. 가마 내부 온도조절은 탐침 전자 온 도계(Center 300k type, YUYU, Korea)를 가마의 상, 중, 하 부에 각각 탐침하여 온도를 모니터링 하였으며 내부 온도 조절이 요구될 때 소량의 나무와 숯을 추가 주입하였다. 가 마를 통해서 태워진 뼈는 상온에서 충분히 식히고 롤 파쇄 기로 파쇄하여 생산된 뼛가루를 $300 \mu \mathrm{m} \sim 600 \mu \mathrm{m}$ 의 체거름기 로 걸러 최종 고흡착 골탄으로 만들었다. 뼈를 태우는 과정 에서 가마의 철문이 고온에 구부러지는 현상이 발생됨에 따 라 연기와 열이 외부로 방출되어 내부 온도변화에 영향을
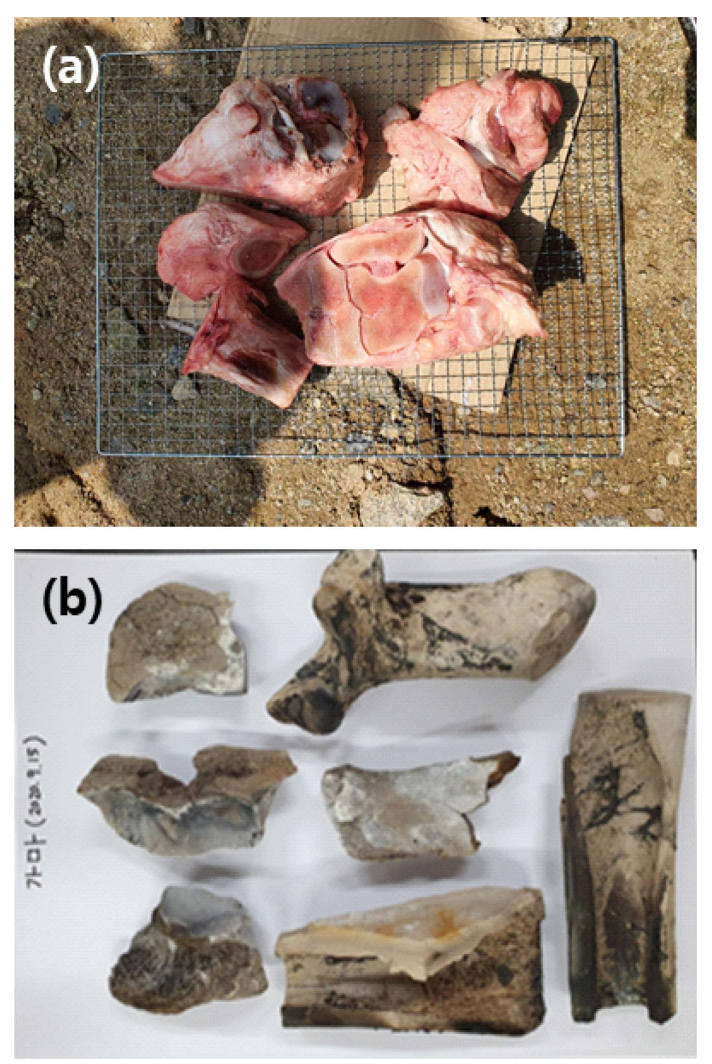

Figure 3. 가마 운영 전 뼈(a), 가마 운영 후 태워진 뼈의 모습(b)
미치는 것을 알 수 있었다.

Figure 3 은 가마에 주입 전 소뼈의 모습(a)과 3 시간 동안 $450 \pm 50^{\circ} \mathrm{C}$ 에서 태워진 후 소뼈의 모습(b)을 보여주고 있다. 태워진 소뼈는 가마를 운영할 때 숫과 나무를 이용하여 화 력을 조절함으로써 내부 온도를 목표치로 유지하여 잘 태 워진 결과를 얻을 수 있었다. 하지만, 프로토타입으로 제작 된 가마는 벽 두께가 얇아서 열 손실이 크고 벽돌 틈새 사 이가 연기가 누출되는 상황이 발생하였다. 현지에서 가마를 제작할 때 이점을 보완하면 효과적인 가마를 운영함으로써 고품질의 고흡착 골탄 생산을 할 수 있는 방안을 마련할 수 있었다.

\section{2. 회분기 실험을 통한 골탄의 수질 분석결과}

현지형 가마를 통해서 제작된 고흡착 골탄과 실험실에서 제작한 골탄 그리고 현지에서 사용되고 있는 골탄을 이용 하여 탁도, TOC, 불소 흡착량 비교 실험 결과를 Table 1에 서 보여주고 있다. 모든 실험은 Batch test를 통해서 수행하 였다. $1 \mathrm{~L}$ 비커 3 개에 $5 \mathrm{mg} / \mathrm{L}$ 의 불소 용액 $1 \mathrm{~L}$ 를 넣고 서로 다른 골탄 $1 \mathrm{~g}$ 씩을 주입하여 최대 1 일 동안 교반 후 탁도, $\mathrm{TOC}$, 불소를 분석하였다. 흡착 실험에 사용된 불소 시약은 ACS 등급인 sodium fluoride(NF, Sigma-Aldrich, USA)을 이 용하였다. 각 샘플의 탁도는 탁도분석장비 $(2100 \mathrm{~N}, \mathrm{HACH}$ Co., USA)을 통해서 측정하였다. 불소 분석은 분광 광도계 (DR5000, HACH Co., USA)를 이용하였다. 유기물 분석은 TOC 분석장치(TOC-L, Shimadzu Co., Japan)을 이용하였다.

Table 1. 골탄의 수질 분석결과

\begin{tabular}{|c|c|c|c|}
\hline $\begin{array}{c}\text { 원수 불소 농도 } \\
(5 \mathrm{mg} / \mathrm{L})\end{array}$ & $\begin{array}{c}\mathrm{Qe} \\
(\mathrm{mg} / \mathrm{g})\end{array}$ & $\begin{array}{c}\text { 탁도 } \\
(\mathrm{NTU})\end{array}$ & $\begin{array}{c}\mathrm{TOC} \\
(\mathrm{mg} / \mathrm{L})\end{array}$ \\
\hline 실험실 & 3.8 & 5.2 & 0.41 \\
\hline 가마 & 3.7 & 6.8 & 0.43 \\
\hline 현지 & 1.0 & 39.6 & 0.70 \\
\hline
\end{tabular}

실험실과 국내에서 제작된 가마의 골탄 $\mathrm{Qe}$ 값은 각각 3.8 과 $3.7 \mathrm{mg} / \mathrm{g}$ 으로 유사한 불소흡착 효율을 나타내고 있다. 이 는 실험실에서 제작된 골탄이 현지형 가마를 통해서 유사 한 결과를 도출할 수 있다는 것을 의미한다. 하지만, 현지 에서 사용 중인 골탄의 Qe 값은 $1.0 \mathrm{mg} / \mathrm{g}$ 으로 고흡착 골탄 이 현지 골탄보다 약 3.7 배 불소흡착 효율이 높다는 것을 알 수 있었다. 또한 가마와 현지의 탁도 결과에서는 각각 6.8 $\mathrm{NTU}, 39.6 \mathrm{NTU}$ 로 가마에서 제작된 골탄의 탁도가 현저히 낮다는 것을 알 수 있다. 현지에서 운영 중인 가마는 온도 조절 능력이 없기 때문에 가마 내부에서 뼈가 불완전한 상 태로 태워져 나오기 때문에 완전 탄화되지 못한 유기물인 
인해 탁도 발생량이 많은 것으로 사료된다. 이처럼 유기물 결과에서도 동일한 결과를 초래할 수 있었다. 유기물은 색 도를 유발하는 물질이기 때문에 최적 온도 조건에서 유기 물을 태우는 것이 골탄 품질을 높이는 요인이다.

\section{탄자니아 현지에서 고흡착 골탄 생산 가마 제작}

\section{1. 현지형 고흡착 골탄 생산을 위한 workshop 구축}

탄자니아 아루샤에 위치한 Gongali에서 Figure 4와 같이 고흡착 골탄 생산을 위해 파쇄기, 절단기, 체거름기 등을 운 영할 수 있는 workshop 1 개 건물을 구축하였다. Workshop 에서는 고흡착 골탄 생산 공정을 전문적으로 운영할 수 있 도록 설계제작 되었다. Workshop 외부에 제작한 현지형 가 마에서 뼈를 태운 후 workshop 내부에서 파쇄, 체거름, 세 척 후 포대에 골탄을 담아 운영된다. 수거해온 뼈와 현지에 서 구매한 숯과 나무 등의 재료들을 workshop에 보관하여 운영하고 있다. 고흡착 골탄을 생산하고 시설을 운영할 수 있도록 Gongali 직원 대상으로 가마 및 workshop 운영을 위 한 기술 전문 교육을 수행하여 현지에서 자체적으로 운영 할 수 있는 역량을 키울 수 있었다. 전문적으로 가마를 운
영할 수 있도록 수차례 시범운행을 수행함으로써 고흡착 골 탄 생산을 위한 전문성을 유도하였다.

\section{2. 현지형 고흡착 골탄생산을 위한 가마 제작}

국내 프로토 타입으로 제작된 가마 설계 조건으로 Gongali 에서 고흡착 골탄 생산을 위한 현지형 가마를 제작하였다. 구축된 가마의 규격은 가로·세로·높이가 $100 \mathrm{~cm}, 130 \mathrm{~cm}$, $230 \mathrm{~cm}$ (굴뚝포함)로 설계하여 만들었다. 가마 내부 열 손실 을 줄이기 위해 가마 벽을 두껍게 제작하였다. 가마의 외쪽 과 오른쪽 측면에는 산소 주입이 원활할 수 있도록 3 개의 공기 구멍을 각각 만들었다. 숯과 나무를 넣어 화력을 지원 할 수 있는 전면부에는 가로·세로 각각 $30 \mathrm{~cm}$ 의 철제문을 장착하였으며 후면부에는 가로·세로 $40 \mathrm{~cm}, 50 \mathrm{~cm}$ 로 철제문 을 장착하였다. 가마를 구축할 때 4단 철제 선반 케이지를 만들어 가마 안쪽에 넣어 제작하였다. 그리고 손잡이가 달 린 4개의 철제 플레이트를 만들어 뼈를 넣고 후면부 철제 문을 열어서 철제 선반 케이지에 넣고 뺄 수 있도록 구성 하였다. 그림 Figure 5는 Gongali에 구축된 현지형 가마의 전 체 모습과 후면부 철제문과 철제 선반 케이지와 철제 플레 이트를 보여주고 있다.
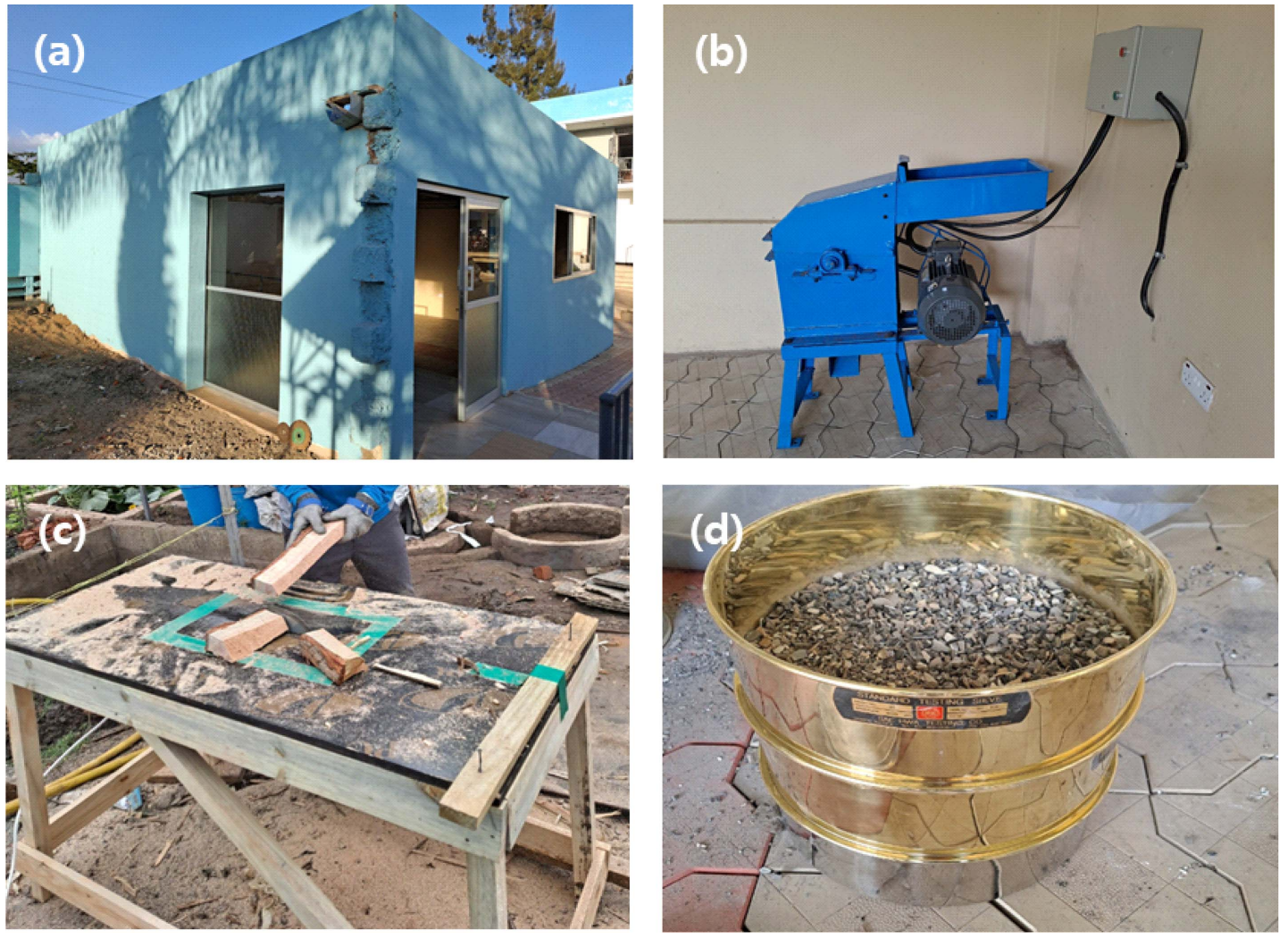

Figure 4. Gongali에 구축한 골탄 제조 작업을 수행하는 workshop(a), 파쇄기(b), 절단기(c), 체거름기(d) 

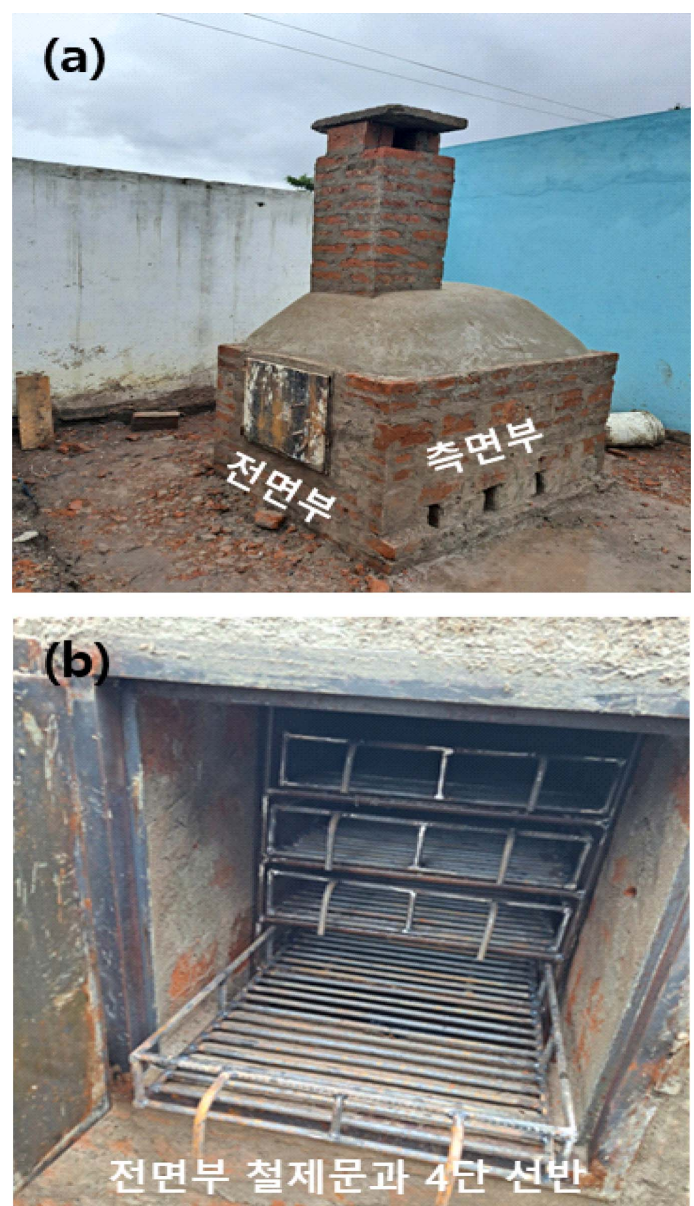

Figure 5. 현지형 가마 제작 모습(a), 뼈를 넣고 뺄 수 있는 4단 철 제 선반(b)

\section{3. 불소 제거 고흡착 골탄 생산}

현지에서 수집한 뼈를 철재로 제작된 4 개 철제 플레이트 에 담아서 철제 선반 케이지에 넣은 후 $450 \pm 50^{\circ} \mathrm{C}$ 에서 3 시 간 동안 뼈를 태웠다. 가마 운전 시 내부 온도를 안정적으 로 유지하기 위해서 가마의 상-하단부에 탐침용 전기 온도 계를 꽂아서 온도변화에 관찰하고 가마 내부 온도가 떨어 질 때 화력과 산소 주입량을 조절함으로써 골탄 제작을 위 한 최적 온도가 유지될 수 있었다. 태우기 전과 후의 모습 은 Figure 6에서 알 수 있으며 태워진 뼈는 파쇄기를 이용 하여 작은 입자로 만든 후 체거름 $(300 ~ 600 \mu \mathrm{m})$ 하여 골탄으 로 사용하였다. 현지에서 수거한 뼈들은 국내에서 구매한 뼈 보다 살점이 많이 없어서 태우는 과정이 더욱 수월하게 진 행될 수 있었다. 1 회 가마를 운영할 때 숯과 나무를 이용하 지만, 숯은 3 시간 이상으로 태울 수 있는 장점이 있기 때문 에 추가 화력지원을 통해서 하루에 총 4 회까지 가마를 운 영할 수 있었다. 1 대의 가마에서 약 $5 \mathrm{~kg}$ 의 뼈를 주입 가능 하며 파쇄, 체거름, 세척 과정에서 일부 손실되어 총주입량
에 약 $60 \%$ 를 생산할 수 있었다. 가마를 통해서 생산된 고 흡착 골탄은 미세한 입자들로 인한 고탁도 탁도 유발이 가 능하기 때문에 물로 세척한 후 건조해서 포대에 넣어 workshop에 보관하여 사용하고 있다. 태워진 뼈를 가마에서 수거할 때 철제 플레이트는 고온에서 구부러진 형상 없어 안정적으로 뼈를 외부로 옮길 수 있었지만, 철의 특성상 무 겁고 고온에 달구어진 철이 뜨거워서 조심스럽게 운영할 필 요가 있었다. 따라서 고온에서 작업 가능한 방열 장갑과 같 은 작업환경이 갖춰지면 더욱 효과적인 가마 운영이 될 수 있을 것으로 사료된다.
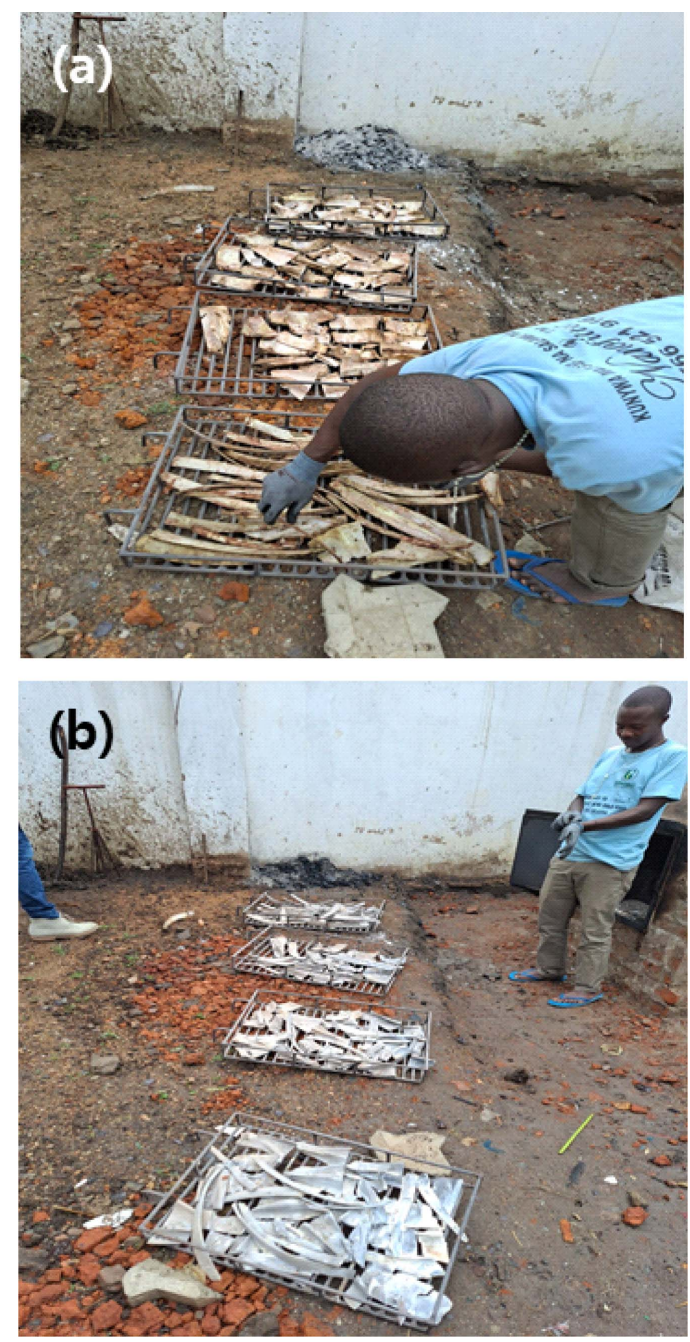

Figure 6. 가마를 이용해서 뼈를 태우기 전의 모습(a)고 태운 후 의 모습(b)

\section{고흡착 골탄을 이용한 NWS pilot plant 운영 및 수질분석}

현지형 가마를 통해서 제작된 고흡착 골탄을 Gongali에 
서 운영하고 있는 NWS 정수장치에 주입하여 불소제거 연 속 장기운전을 하였다. NWS 정수 장치는 Figure 7과 같이 1) 원수탱크, 2) 골탄컬럼, 3) 모래 필터, 4) 무동력 UF membrane, 5) 처리수 탱크의 공정으로 되어 있다. 모래필터 는 UF membrane의 전처리 용도로 사용되고 있으며 특히, 골탄컬럼에서 유출되는 미세입자들을 제거하기 위해 운영 하고 있다. NWS는 탄자니아 정부에서 운영하고 있는 먹는 물 수질기준에 적합한 장치로 인가를 받아 운영하고 있다. $\mathrm{NWS}$ 의 주입 원수는 수돗물 $(3.8 \mathrm{mg} / \mathrm{L})$ 을 사용하였으며 유입 유량은 $100 \mathrm{~L} / \mathrm{d}$ 로 운전하고 있다. 원수는 수도꼭지에서 원 수탱크로 저장된 후 유입유량을 조절하여 골탄컬럼으로 들 어가 불소가 제거된 후 모래필터와 무동력 UF membrane 필터를 거쳐서 처리수 탱크에 저장된다. 처리수의 탁도 및 불소 농도를 일정한 간격으로 현장에서 분석하여 기록하고 있다.

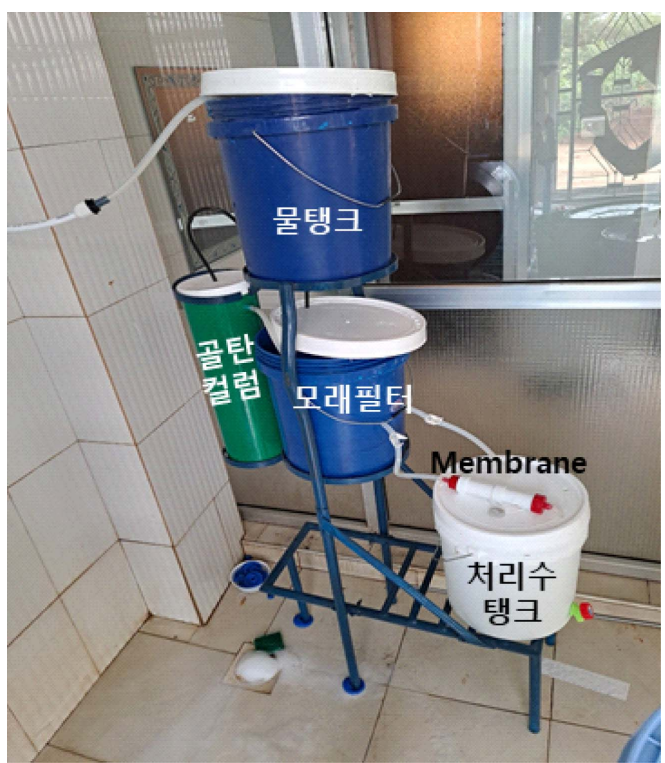

Figure 7. 고흡착 골탄을 이용한 NWS 정수장치

현지 골탄으로 NWS를 운영할 경우 초기 처리수 색도가 발생하여 식수로 음용하기에 적합하지 못했지만, 고흡착 골 탄은 초기 처리수에 색도가 발생하지 않다는 것을 실험결 과를 통해서 확인 할 수 있었다. Figure 8 에서 기존 골탄과 고흡착 골탄의 초기 처리수 색도를 비교한 사진을 볼 수 있 다. 또한, 기존 골탄을 이용할 때 앞선 연구 결과에서 언급 한 것처럼 초기 처리수에서 고탁도가 발생되는 문제가 있 지만, NWS는 골탄컬럼 이후에 모래필터와 UF membrane을 이용하여 탁도는 제어해 주기 때문에 처리수 탁도에는 큰 영향을 미치지 않는 것으로 확인 되었다. NWS 연속 장기 운전은 2021년 2월에 실험을 시작하여 3개월이 지난 현재
도 여전히 처리수 불소 농도는 $0.31 \mathrm{mg} / \mathrm{L}$ 로 $\mathrm{WHO}$ 불소수질 기준인 $1.5 \mathrm{mg} / \mathrm{L}$ 에 미치지 않는 것으로 확인 되었다. 상대 적으로 현지 골탄의 교체 주기가 대체적으로 3 개월이기 때 문에 현시점에서 교체가 요구되어 비용이 발생한다. 따라서 고흡착 골탄을 이용한 NWS 식수 장치는 골탄 교체 비용을 줄일 수 있으며 안전한 식수를 저렴하게 주민들에게 공급 할 수 있는 개발도상국형 식수 적정기술이다.

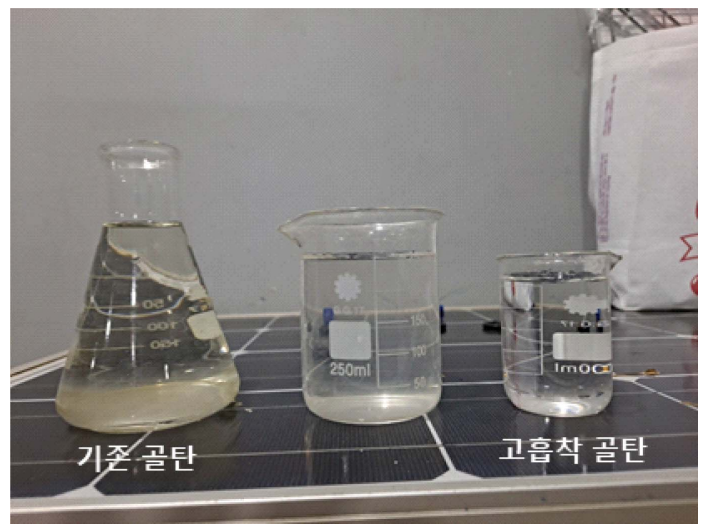

Figure 8. 기존골탄을 이용한 처리수(왼쪽) 색도와 현지에서 생산 한 고흡착 골탄을 이용한 처리수(오른쪽) 색도 결과 비교

Figure 9는 NWS에서 판매되고 있는 식수를 채수하여 수 질조사 검사서를 발생한 자료이다. 지역에 구축된 90개의 NWS로부터 식수를 주기적으로 채수하여 Gongali에서 운영 하는 $\mathrm{Lab}$ 에서 담당 수질 분석가에 의해서 수질검사를 수행

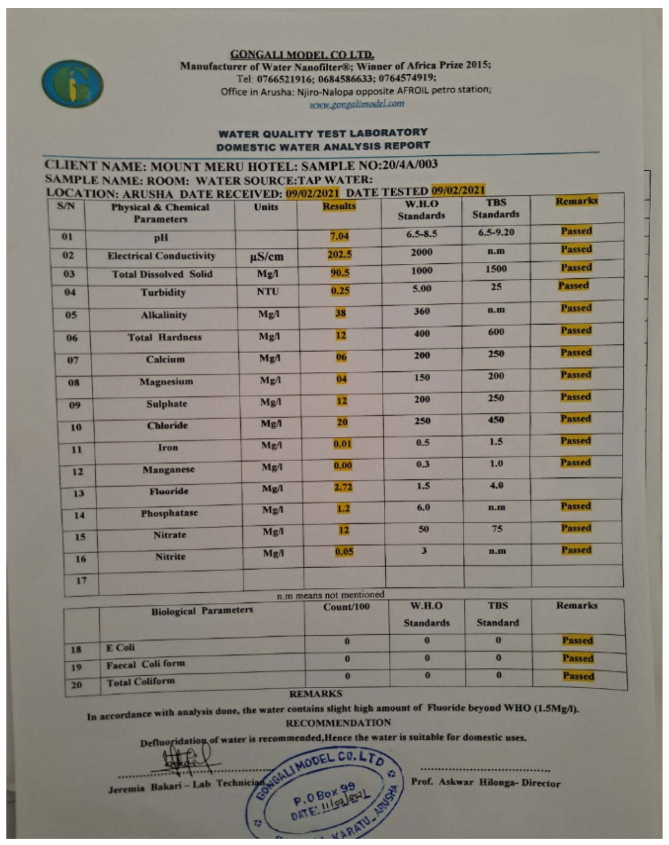

Figure 9. NWS 현지 먹는 물 수질 검사서 
하고 있다. 수거한 샘플의 수질 결과는 WHO와 탄자니아 수 질기준에 초과하는 여유를 명시하여 판매자들에게 보고한 다. 탄자니아 아루샤 지역의 지하수 수질은 대체로 좋지만, 불소 농도가 높기 때문에 흡착 컬럼을 이용하여 불소가 제 거된 안전한 식수를 공급하는것에 큰 중점을 두고 있다.

\section{지속 가능한 NWS 운영 비즈니스 모델 개발}

\section{1. 고흡착 골탄과 기존 골탄의 경제성 비교}

Gongali는 현지에서 생산한 골탄을 이용하여 안전한 식수 를 공급하는 사업을 진행하고 있었지만, NWS 운영비에 큰 부담을 느끼고 있었다. NWS의 전체 운영비에서 약 $33 \%$ 가 골탄 교체 비용을 발생하고 있어 Gongai CEO는 NWS 운 영상에 어려움이 있다고 호소하고 있다. 현재 NWS의 전체 운영비가 TZS 30,000(3개월)이라면 그중 골탄 교체비용이 TZS 10,000(3개월)이 요구된다고 전달받았다. 그렇기 때문 에 본 사업에서 제작한 고흡착 골탄을 이용할 때 이론적 흡 착량 대비 교체주기를 계산하면 11.1 개월이 소요되기 때문 에 기존 골탄교체 비용의 $78 \%$ 의 절감 효과를 얻을 수 있다. Figure 10은 기존 골탄과 고흡착 골탄의 교체 주기를 비교 하여 보여주고 있다. Gongali에서는 3개월마다 90곳에 달하 는 NWS의 골탄을 교체하고 있기 때문에 수질 분석을 통한 불소 농도 모니터링과 골탄 교체일이 큰 비용과 상당한 업 무에 속하고 있다. 하지만, 고흡착 골탄을 이용하여 약 11.1 개월에 한 번씩 골탄을 교체하게 되면 동일 인건비 대비 운 영비를 줄일 수 있다는 장점이 있다.

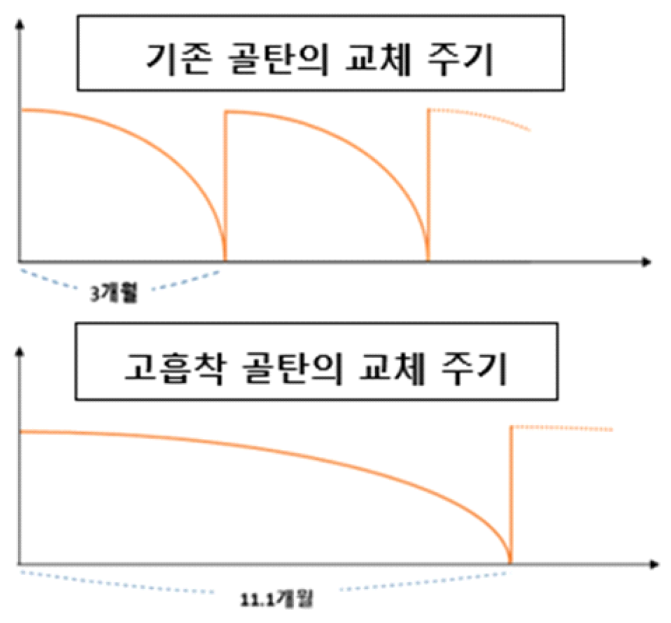

Figure 10. 기존골탄과 고흡착 골탄의 교체 주기

Table 2는 기존골탄과 고흡착 골탄을 12 개월 동안 운영하 고 교체할 때 NWS 1 개와 90 개에서 소요되는 교체 비용을 비교하여 보여주고 있다. 90 개의 NWS에서 기존 골탄으로
운영 후 교체할 때 드는 비용이 TZS $3,599,640$ 이며 고흡착 골탄으로 운영 후 교체할 때 드는 비용이 TZS 972,000로 알 수 있었다. 결과적으로 고흡착 골탄을 이용할 때 기존 골탄 보다 연간 TZS $2,627,640$ 을 절감할 수 있는 경제적 효과를 얻을 수 있다. 이는 판매자들의 수입 증대 효과를 줄 수 있 을 뿐만 아니라 주민들에게 안정적으로 안전한 식수를 지 속해서 공급할 수 있다는 이점이 있다. 또한, Gongali는 아 루샤 정부에서 판매하는 기존 골탄을 TZS $5,000 / 5 \mathrm{~kg}$ 에 구 매하여 NWS를 운영하고 있었지만, 가마에서 직접 고흡착 골탄은 대량 생산할 수 있기 때문에 구매 비용도 절감 되 어 Gongali에서는 추가적으로 경제적인 수익을 발생시킬 수 있는 계기가 될 수 있다. 이처럼 고흡착 골탄은 다양한 측 면에서 수익이 누적되어 많은 사업을 지속가능하게 운영할 수 있는 기회를 제공할 수 있다. 또한, 저소득층과 소외계 층에게도 안전한 식수를 공급할 수 있는 제공의 기회로 $\mathrm{NWS}$ 를 확산 보급할 수 있다.

Table 2. 기존 골탄과 고흡착 골탄의 교체 비용 비교

\begin{tabular}{|c|c|c|c|}
\hline Nanofilter water station & 통화 & $\begin{array}{c}1 \text { 개 } \\
\text { (12개월) }\end{array}$ & $\begin{array}{c}90 \text { 개 } \\
\text { (12개월) }\end{array}$ \\
\hline 기존 골탄 교체 비용(A) & TZS & 39,996 & $3,599,640$ \\
\hline 고흡착 골탄 교체 비용(B) & TZS & 10,800 & 972,000 \\
\hline (A)-(B) (비용절감) & TZS & 29,196 & $2,627,640$ \\
\hline
\end{tabular}

\section{2. 현지 자급형 NWS 비즈니스 운영 모델 개발}

Gongali는 기술분야 및 분석분야의 전문 엔지니어와 Lab 분석사를 보유하고 있다. NWS의 설계 및 조립 그리고 $\mathrm{A} /$ $\mathrm{S}$ 업무까지 다양한 기술 지원이 가능한 엔지니어들이 상주 하여 업무를 수행하고 있으며 자체적인 기술 역량이 충분 하다. 또한, 수질 분석을 담당하는 $\mathrm{Lab}$ 분석사를 통해서 $\mathrm{NWS}$ 의 불소 농도를 지속적으로 모니터링하여 골탄의 교체 시점을 결정하는 업무를 수행하고 있다. Gongali는 기존 현 지 골탄을 사용하면서 교체비용 및 수질관리 문제에 어려 움이 많았지만, 현재는 고흡착 골탄 생산기술 이전을 통해 서 어려웠던 문제들이 해결되어 NWS의 판매자들과 식수를 구매하는 소비자들의 만족도가 높아질 것으로 사료 된다. 하 지만 NWS의 필터 구성품인 UF membrane은 우리나라 중 소기업에서 개발한 제품이다. 그렇기 때문에 NWS 확산을 위해서 Gongali는 지속해서 UF membrane을 구매할 필요가 있다. 이처럼 대부분의 개발도상국 대상의 ODA 사업들은 최초 사업을 수행하면서 현지에 국내의 좋은 기술들을 제 공하고 지원할 수 있지만, 단발성 사업으로 인해 추가적인 지원 대안이 마련되지 못한 채 사업을 마무리 경우가 많았 다. 하지만 Gongali는 국내 UF membrane을 현지에서 구매 
가능한 기업과 협력하여 UF membrane을 지속적으로 조달 할 수 있었기 때문에 Gongali에 고흡착 골탄을 지원하게 되 면 NWS를 더욱 효과적으로 운영할 수 있다는 확산을 갖게 되었다. 따라서 NWS의 지속 가능한 운영 및 확산을 위해 서 Gongali에서는 고흡착 골탄 생산기술을 이전받아 충분 히 자립하여 운영할 수 있는 비즈니스 모델을 구축할 수 있 다. Figure 11에서 보여준 것 과같이 Gongali는 기술지원역 량과 현지에서 국내 UF membrane을 구매할 수 있다는 큰 장점으로 현재까지 90 개의 NWS를 보급하였지만, 지금은 국내에서 기술지원한 고흡착 골탄생산 기술을 이전받아 이 전보다 많은 수익을 창출하여 91개 이상의 NWS를 구축할 수 있는 역량을 갖추게 되었다. 또한, 지속해서 증가하는 NWS는 국내 UF membrane을 제작하는 판매하는 중소기업 의 매출 증대를 기대할 수 있으며 해외사업 진출에 대한 가 능성을 제시할 수 있다는 큰 장점을 갖고 있다. 따라서 우 리나라 정부의 $\mathrm{ODA}$ 사업은 국내 물 사업과 현지 물 산업 을 동시에 성장시킬 수 있는 비즈니스 모델을 구축하기 위 한 미래 지향적인 목적으로 사업을 추진하였다.

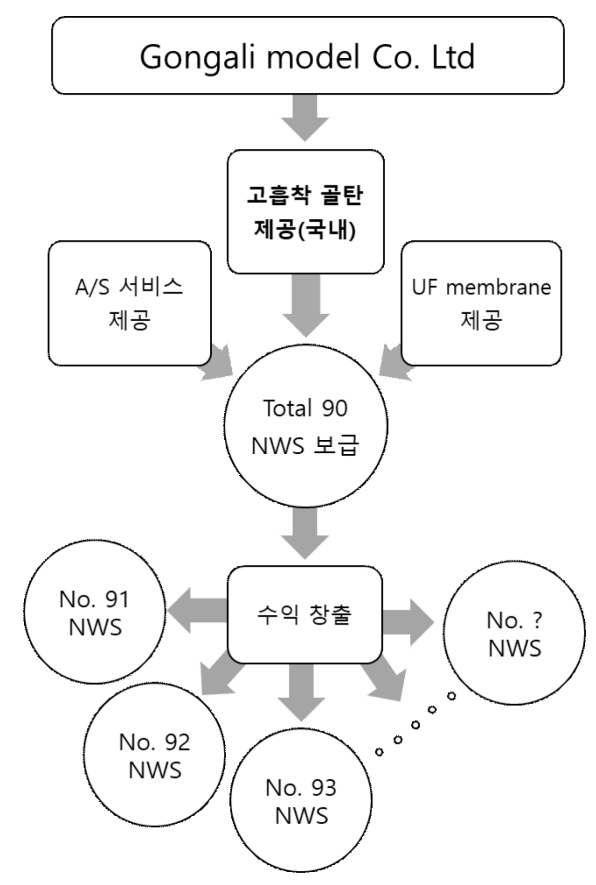

Figure 11. NWS 현지 지속가능 모델

\section{Conclusion}

지속 가능한 적정기술이 현지에서 운영할 수 있는 역량 이 충분한지 현지협력기관의 상황을 우선적으로 면밀히 파 악할 필요가 있다. 현지의 필요를 일방적인 연구 견해로 인
해 수행되는 사업들이 많았기 때문에 적정기술의 지속 가 능성이 현지에서 서툴게 진행되지 않았나 싶다. 본 사업은 탄자니아 아루샤에 위치한 사회적 기업인 Gongali라는 회 사가 지역사회의 저소득층과 소외계층에게 안전한 식수를 공급할 수 있는 NWS를 자체 개발하여 식수 사업을 수행하 고 있다는 관점에서 Gongali의 기술적 역량이 충분하다는 것을 확인 할 수 있었다. 따라서 본 연구기관에서는 고흡착 골탄을 생산할 수 있는 현지형 가마 기술을 Gongali에 이전 할 때 향후 NWS 확산에 큰 영향을 미칠 수 있다는 것을 확 신할 수 있었다. Gongali는 기존 골탄을 사용하면서 교체 비 용이 사업 수행에 큰 부담으로 직면한 상태였기 때문에 경 제성이 좋은 고흡착 골탄 생산 기술 이전에 큰 관심을 갖 고 있었기 때문에 본 사업을 수행하는 과정에 상호 협력적 인 관계로서 수월하게 사업을 진행할 수 있었다. 따라서 현 지 기관의 상황과 사업 구조를 이해하고 이를 해결해줄 수 있는 방안을 마련하는 방안으로서 적정기술이 적용한다면 지속 가능한 NWS 사업을 추진할 수 있으며 국내 환경기업 들의 해외 진출에서도 큰 영향을 미칠 수 있다는 가능성을 본 사업을 통해서 제시할 수 있다.

\section{Acknowledgment}

본 연구는 한국연구재단 연구비를 지원받아 수행되었습 니다(과제번호: 2017K1A3A904013880).

\section{References}

Aklil, A., Mouflih, M., and Sebti, S. (2004). Removal of heavy metal ions from water by using calcined phosphate as a new adsorbent, J. Hazard. Mater., 112(3), pp. 183-190.

Colombani, N. D., Di, G. S., Kebede, M., and Mas, T. (2018). Assessment of the anthropogenic fluoride export in Addis Ababa urban environment (Ethiopia), J. Geochem. Explor, 190, pp. 390-399.

Hu, J., Wu, R., Rao, R., Liu, R., and Lai, W. (2017). Adsorption kinetics of fluoride on bone char and its regeneration, Environ, Prot. Eng., 43(3), pp. 93-112.

Imran, H., and Mithas, A. D. (2013). Perspectives in water pollution. Open Sci., Intech, pp. 71-75.

Jeremy, A. H., Jason, M. T., and Peter, M. M. (2018). Fluorides and other preventive strategies for tooth decay, Dent. Clin. North. Am., 62, pp. 207-234.

Kaseva, M. E. (2006). Optimization of regenerated bone char for fluoride removal in drinking water: a case study in Tanzania, J. Water and Health, 4(1), pp. 139-147. 
Kut, K. M. K., Sarswat. A., Srivastava. A., and Pittman Jr, C. U. (2016). Review of fluoride in african groundwater and local remdiation methods, Groundw. Sustain. Dev., 2-3, pp. 190212.

Leyva-Ramos, R., Rivera-Utrilla, J., Medllin-Castilo, N. A., and Sanchez-polo, M. (2010). Kinetic modeling of fluoride adsorption from aqueous solution onto bone char, Chem. Eng. J., 158(3), pp. 458-467.

Li, Y., Ling, C. W., Slemenda, Ji, R. Sun, S., Cao, J., Emsley, C. L., Ma, F., Wu, Y., Ying, P., Gao, S., Zhang, W., Katz, B. P., Niu. S., Cao. S., and Johnston Jr. C. C. (2016). Effect of long-term exposure to fluoride in drinking water on risks of bone fractures, J. Bone Miner. Res., 16(5), pp. 932-939.

Loganathan, P., Vigneswarna, S., Kandasamy, J., and Naidu, R. (2013). Defluoridation of drinking water using adsorption processes, J. Hazard. Mater., pp. 248-249.

Maeng, M. S., Byun, J. S., Park, H. J., and Shin, G. A. (2020). Optimum operating conditions of drinking water treatment system for fluoride removal using high adsorption bone char, 42(11), pp. 520-528.

Malago, J., Makoba, E., and Muzuka, A. N. N. (2017). Fluoride levels in surfacr and groundwater in Africa: a review, Am. J. Water. Sci. Eng., 3(1), pp. 1-17.

Medlin-Castillo, N. A., Leyva-Ramos, R., Ocampo-Perez, R., Garcia de la Cruz, R. F., Aragon-Pina, A., Martinez-Rosales, J. M., Guerrero-Coronado, R. M., and Fuentes-Rubio, L.
(2007). Adsorption of fluoride from water solution on bone char, Ind. Eng. Chem. Res., 46(26), pp. 9205-9212.

Medellin-Castillo, N. A., Padilla-Ortega, E., Tovar-Garcia, L. D., Leyva-Ramos, R., Ocampo-Perez, R., Carrasco-Marin, F., and Berber-Mendoza, M. S. (2016). Removal of fluoride from aqueous solution using acid and thermally treated bone char, Adsorption, 22, pp. 951-961.

Mohapatra, M., Anand, S., Mishra, B. K., Giles, D. E., and Singh, P. (2009). Review of fluoride removal form drinking water, J. Environ. Manag., 94(1), pp. 67-77.

Moreno-Pirajan, J. C., Giraldo, L., and Garcia-Cuello, V. S. (2011). Study of the textural proerties of bovine bones char under different conditions, J. Water. Res. Prot., 3(3), pp. 176181.

Nair, K. R., and Gitonga, J. N. (1984). The occurrence and distribution of fluoride in groundwater of Kenya, Challenges in African Hydrology and Water Resources, in Proceedings of the Harare Symposium, 144, pp. 75-86.

Vithanage, M., and Bhattacharya, P. (2015). Fluoride in the environment: sources, distribution and defluoridation, Environ. Chem. Lett., 13, pp. 131-147.

Zuniga-Muro, N. M., Bonilla-Petriciolet, A., Mendoza-Castillo, D. I., Reynel-Avila, H. E., and Tapia-Picazo, J. C. (2017). Fluoride adsorption properties of cerium-containng bone char, J. Fluorine Chem., 197, pp. 63-73. 